\title{
PENDIDIKAN KOGNITIF DAN AFEKTIF DAGUSIBU UNTUK PENCEGAHAN RESISTENSI ANTIBIOTIK DI SMA SURABAYA
}

\author{
Abhimata Paramanandana ${ }^{1}$, Dini Retnowati ${ }^{1}$, Andang Miatmoko ${ }^{1}$, Dewi Isadiartuti ${ }^{1}$, Sugiyartono $^{1}$, Mohammad \\ Agus Sjamsur Rijal ${ }^{1}$, Dwi Setiawan ${ }^{1}$, Esti Hendradi ${ }^{1}$, Tutiek Purwanti ${ }^{1}$, Noorma Rosita ${ }^{1}$, Dewi Melani \\ Hariyadi $^{1}$, Tristiana Erawati ${ }^{1}$, Ardhani Dwi Lestari ${ }^{1}$, Helmy Yusuf ${ }^{1}$, Retno Sari ${ }^{1}$
}

\author{
1) Departemen Farmasetika, Fakultas Farmasi, Universitas Airlangga \\ E-mail: abhimata.p@ff.unair.ac.id
}

\begin{abstract}
Antibiotics are not only used for humans, but also often used for cattle and livestock which are then been consumed by humans. This over prescribed and missed used of antibiotic is a major factor in antibiotic resistance. Antibiotic resistance is a condition where bacteria are unable to be treated with antibiotics. In fact, the use of antibiotics is the first response in curing infectious diseases (by bacteria) and preventing infectious diseases spreading. With antibiotic resistance, preventing infectious diseases by bacteria became harder. This community service activity came up with a slogan "Antibiotic Resistence Awareness Movement" was carried out in Surabaya 10 Public High Schools and Surabaya 17 Public High Schools with 60 students per school using several methods, namely: (a) giving lecture material using LCD projectors ) the implementation of poster making competitions, and (c) poster presentations that have been made that are accompanied by question and answer, and (d) evaluation activities in the form of written tests covering pre-test and post-test. Concerning the results of posters results, poster presentations and improving the results of this posttest can be concluded as a result of an increase in understanding and or knowledge of students of SMA 10 and SMA 17 Surabaya
\end{abstract}

Keyword: antibiotic, antibiotic resistance, DAGUSIBU, High Schools Students, posters presentations, antibiotic resistance awareness.

\section{PENDAHULUAN}

Pada dewasa ini, penggunaan antibiotik tidak hanya pada manusia, tetapi juga pada hewan dan ternak yang kemudian dikonsumsi oleh manusia (Witte, 1998). Penggunaan antibiotik secara bebas dan tidak tepat ini merupakan faktor utama terjadinya resistensi antibiotik (Levy, 1998). Resistensi antibiotik merupakan keadaan dimana bakteri tidak dapat dibunuh dengan antibiotik (Davies \& Davies, 2010). Padahal, penggunaan antibiotik merupakan respon pertama dalam menekan penyebaran penyakit infeksi. Dengan adanya resistensi antibiotik makin sulitnya mencegah penyakit infeksi oleh bakteri (Davies \& Davies, 2010).

Berdasarkan WHO, antibiotik resistensi merupakan permasalahan global yang sangat berbahaya karena sulit dalam penanganan penyakit infeksi. Penyakitpenyakit dengan resiko tinggi dapat berakibat kepada kematian seperti pneumonia, tuberculosis, sepsis, gonorrhoea ataupun penularan penyakit melalui makanan semakin sulit untuk diobati. Pada tahun 2013 terdapat 480.000 kasus baru multidrug-resistent tuberculosis (MDR-TB) di dunia (www.who.int). Sedangkan hasil penelitian Antimicrobial Resistance in Indonesia, pada tahun 2000-2004 di RSUD Dr. Soetomo Surabaya dan RSUP dr. Kariadi Semarang, membuktikan bahwa sudah terdapat kuman multi-resisten seperti MRSA (Methicillin Resistant Staphylococcusaureus) dan bakteri penghasil ESBL (Extended Spectrum Beta Lactamases) (www.dinkes.go.id).

Pengetahuan mengenai antibiotik dan penggunaannya merupakan hal yang sangat penting, karena obat sebagai komoditi 
kesehatan harus dikelola dengan benar agar memiliki manfaat bagi seluruh lapisan masyarakat mulai dari anak-anak sampai orang dewasa. Penggunaan antibiotika yang tidak tepat dan tidak tuntas merupakan salah satu faktor utama mempercepat proses resistensi antibiotik. Pengetahuan tentang antibiotik yang benar harus ditanamkan sejak dini untuk mencegah penyebaran informasi yang tidak tepat, serta penyalahgunaan dan pengguna-salahan antibiotik, terutama bagi generasi muda khususnya remaja usia 15-18 tahun. Pada usia remaja akan terjadi perkembangan fisik dan mental yang cepat, dimana dalam proses perkembangan tersebut rentan terhadap kesalahan informasi dan terjadi penyesuaian mental serta pembentukan sikap dan nilai (Hurlock, 1999).

\section{METODE PELAKSANAAN}

Kegiatan pengabdian masyarakat "Gerakan Siswa Sadar Resistens Antibiotik" dilaksanakan dengan menggunakan beberapa metode, yaitu: (a) pemberian materi ceramah tentang DAGUSIBU dengan menggunakan LCD proyektor, (b) pelaksanaan lomba pembuatan poster permainan, dan (c) Mempresentasikan poster yang telah dibuat yang disertai tanya jawab, serta (d) evaluasi kegiatan berupa tes tertulis yang meliputi pre-test dan post-test.

Kegiatan Pengabdian Kepada Masyarakat ini akan dilaksanakan dalam beberapa tahap dengan waktu pelaksanaan yang berbeda ( $2 \mathrm{x}$ pertemuan). Pertemuan pertama diawali dengan pengambilan data berupa kuisioner dan pretest untuk mengetahui tingkat pemahaman siswa mengenai antibiotik. Setelah itu dilakukan penyampaian materi untuk memberikan penjelasan tentang antibiotik, resitensi antibiotik dan solusi penanggulangannya melalui jargon DAGUSIBU dan posttest. Pada akhir pertemuan pertama tugas membuat poster dan dipresentasikan para pertemuan kedua. Waktu yang diberikan untuk membuat poster selama 2-3 minggu.

Kegiatan pengabdian masyarakat ini dilakukan kepada 60 siswa kelas XII SMA Negeri 10 Surabaya dan 60 siswa kelas XII SMA Negeri 17 Surabaya. Siswa dibagi menjadi 11 kelompok dengan topik-topik tertera pada Table 1.

\section{Tabel 1 Topik dan Subtopik Antibiotik, Resistensi Antibiotik dan DAGUSIBU}

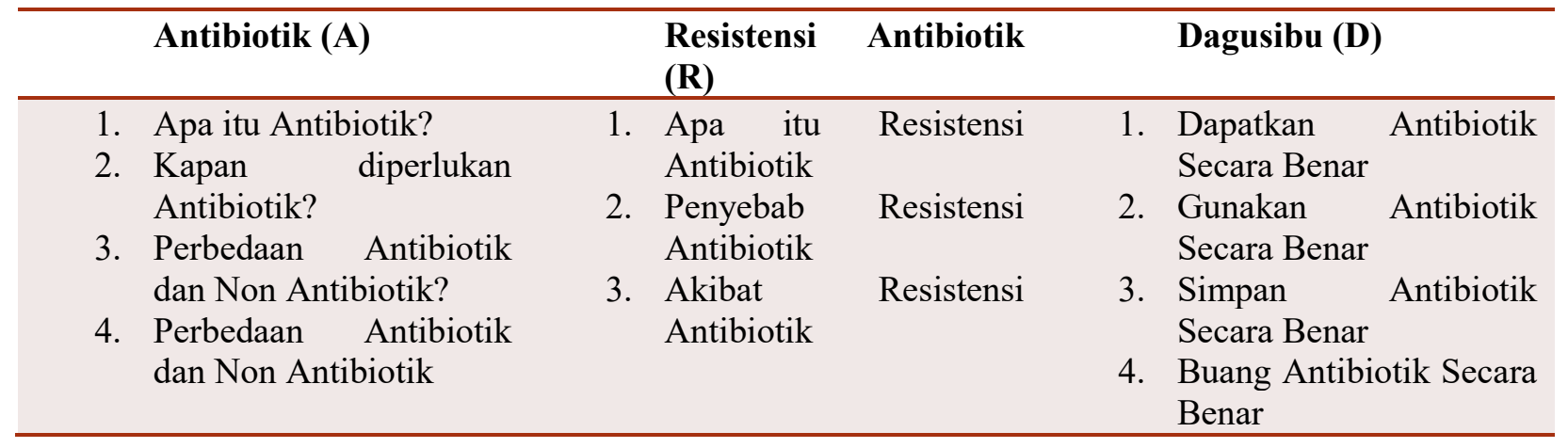

Adapun kriteria penilaian poster meliputi (a) keindahan, (b) kreativitas dan (c) kesesuaian materi sedangkan penilai presentasi poster meliputi (i) keaktifan dan ketepatan menjawab, (ii) kekompakan dan (iii) efisiensi waktu. Tingkat keberhasilan kegiatan diukur dari hasil analisis pre- dan post-test terhadap siswa peserta pelatihan.
Pada sesi penutupan, kepada para siswa tersebut diberikan reward/hadiah untuk peserta terbaik I, II, dan III, serta pemberian kenang-kenangan kepada pihak sekolah. 


\section{HASIL DAN PEMBAHASAN}

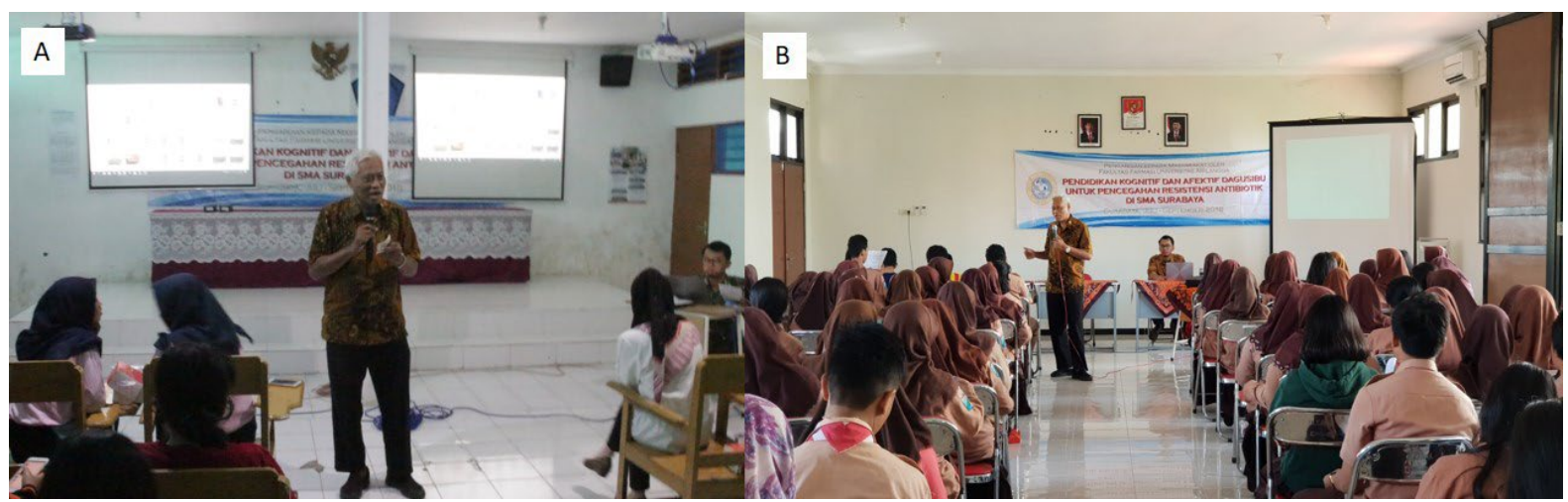

Gambar 1. Pemberian materi oleh fasilitator dari Fakultas Farmasi Universitas Airlangga pada pelaksanaan kegiatan pengabdian masyarakat "Gerakan Generasi Muda Sadar Resistensi Antibiotik Pendidikan Kognitif dan Afektif Bagi Siswa SMA di Surabaya" di SMA Negeri 17 Surabaya (a) dan SMA Negeri 10 Surabaya (b).

Pelatihan ini diikuti oleh sebanyak 67 siswa kelas XII dari SMA Negeri 10 Surabaya (Gambar 1a) dan 65 siswa dari SMA Negeri 17 Surabaya (Gambar 1b). Selama pelatihan terjadi proses pembelajaran dari definisi antibiotik, perbedaan antibiotik dan non antibiotik, definisi resistensi dan penyebab antibiotik serta tentang cara memperoleh, penggunaan, penyimpanan dan pemusnahan antibiotik secara benar sehingga pada akhir pelatihan terjadi peningkatan pemahaman tentang penggunaan antibiotik secara benar. Hal ini dapat dilihat dari hasil pre-test dan post-test peserta.

Dari hasil evaluasi pelaksanaan pretest dan post-test, diperoleh nilai para siswa sebagaimana dapat dilihat pada Gambar 2ab. Siswa SMA Negeri 10 menunjukkan sebaran merata dengan menjawab 6 hingga 10 soal secara benar. Sebanyak 15 siswa memperoleh nilai 7 dan 8 dari skala 10 . Sementara pada pelaksanaan post-test, nilai ujian rerata para siswa mengalami peningkatan dengan 65 siswa memperoleh nilai 9 dan 10, dan hanya hanya 2 siswa memperoleh nilai 8 dari skala 10 . 

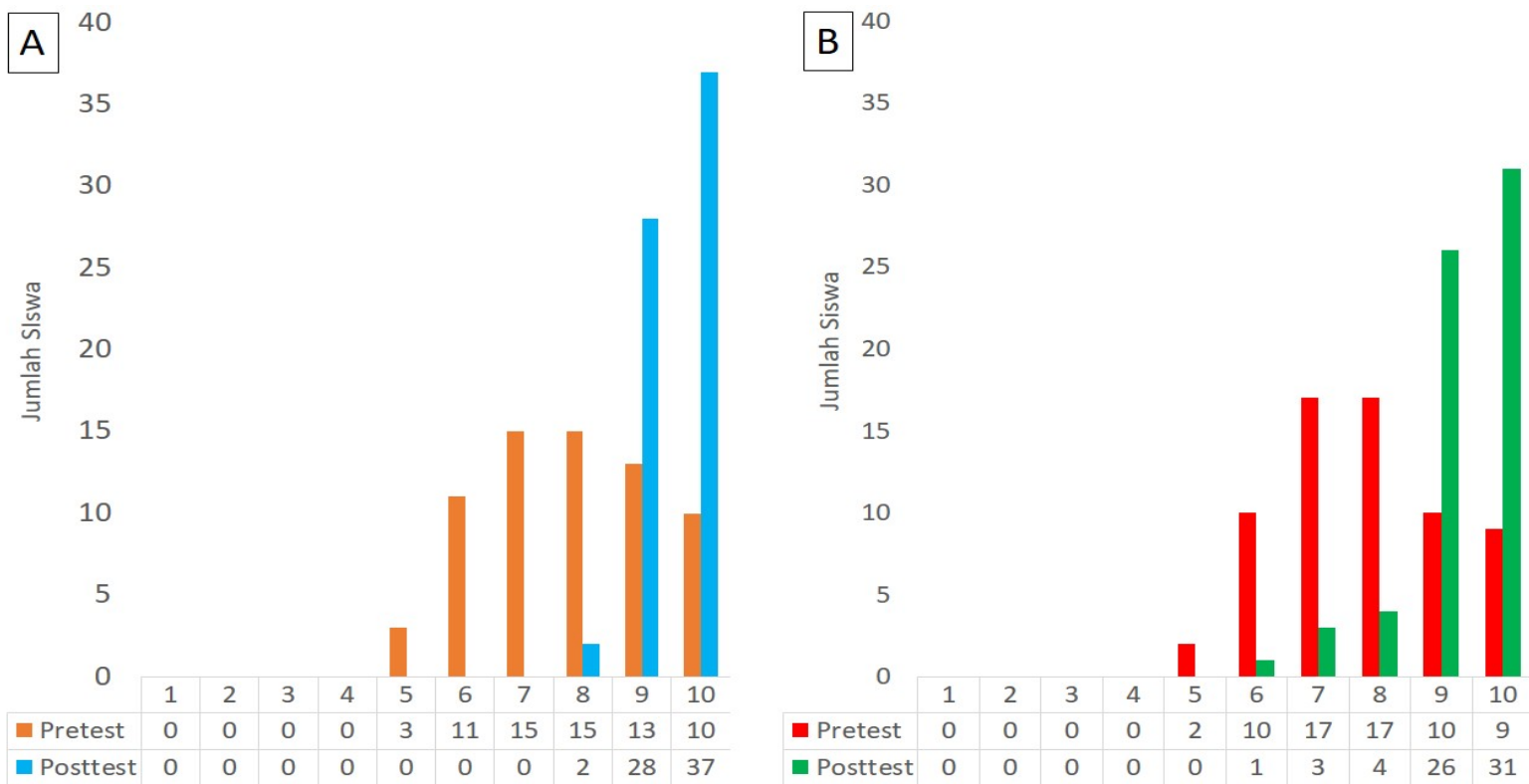

Gambar 2. Hasil Penilaian Pretest dan Posttest SMA Negeri 10 Surabaya (A) SMA Negeri 17 Surabaya (B)

Untuk SMA Negeri 17 Surabaya, hasil pretest dan posttest identik dengan hasil yang ditunjukkan pada siswa-siswa SMA Negeri 10. Mayoritas siswa SMA Negeri 17 dapat menjawab 7 hingga 8 pertanyaan dengan benar pada pretest. Sedangkan pada posttest, sebanyak 57 siswa dari 65 siswa SMA Negeri 17 dapat menjawab 9 hingga 10 pertanyaan dengan benar. Berdasarkan hasil tersebut, dapat terlihat bahwa terjadi peningkatan nilai ujian para siswa sebelum dan sesudah pemberian antibiotik, resistensi antibiotik, dan DAGUSIBU antibiotik. Peningkatan nilai ini dapat disimpulkan sebagai hasil peningkatan pemahaman dan atau pengetahuan dari siswa SMA Negeri 10 maupun SMA Negeri 17 Surabaya.

Selain hasil pretest dan posttest, dilakukan juga lomba pembuatan poster dan presentasi poster sebagai upaya evaluasi pemahaman para siswa mengenai materi antibiotik, resistensi antibiotik dan DAGUSIBU sekaligus sebagai wadah bagi mereka untuk memahami materi DAGUSIBU melalui bentuk kompetisi kreatif, sebagaimana contoh poster terlihat pada Gambar 3. 
Abhimata et.al. Pendidikan Kognitif Dan Afektif Dagusibu Untuk Pencegahan Resistensi Antibiotik Di Sma Surabaya

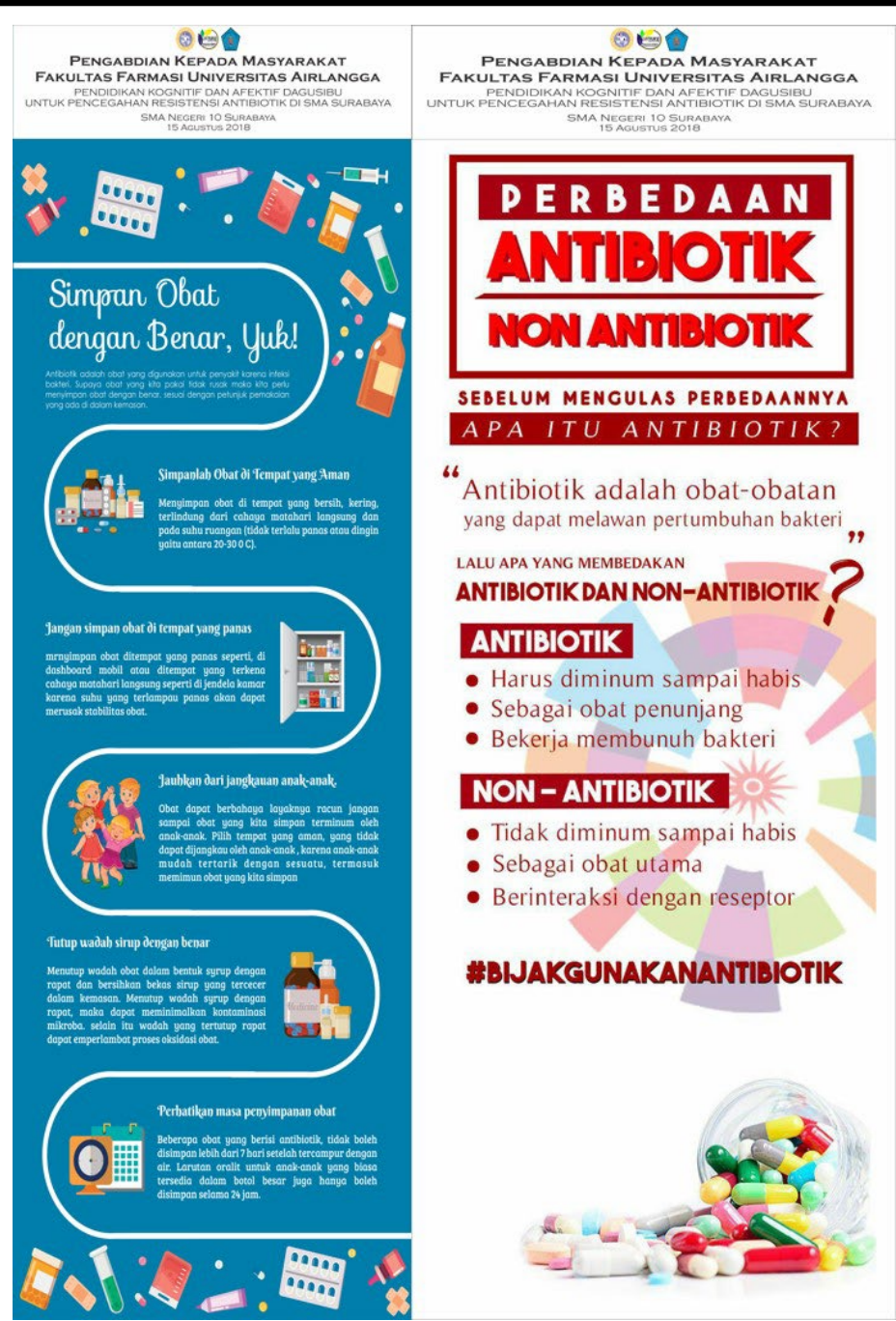

Gambar 3. Hasil Lomba Poster kegiatan pengabdian masyarakat "Gerakan Generasi Muda Sadar Resistensi Antibiotik Pendidikan Kognitif dan Afektif Bagi Siswa SMA di Surabaya"

Berdasarkan evaluasi perlombaan, secara umum siswa telah mampu secara kreatif menciptakan poster-poster dan melakukan presentasi dengan baik sebagai sarana untuk promosi DAGUSIBU. Pelatihan yang diberikan telah berhasil memberikan pengetahuan tambahan dan pemahaman tentang antibiotik, bahaya dan cara menghambat resistensi antibiotik dengan cara secara sadar mendapatkan, menggunakan, menyimpan, dan membuang obat dengan benar. Media-media promosi ini diharapkan dapat menjadi salah satu sarana untuk mempromosikan DAGUSIBU untuk penggunaan obat secara benar di masyarakat, khususnya dalam menciptakan generasi muda yang sadar obat.
Pada penyuluhan ini, para siswa sangat antusias dengan adanya tambahan pengetahuan dan wawasan dalam bidang obat-obatan, khususnya antibiotik yang ditunjukkan oleh banyaknya pertanyaan dan diskusi yang ditunjukkan oleh peserta penyuluhan. Oleh karena itu, dirasakan perlu dilakukan kegiatan pengabdian masyarakat lanjutan dengan sasaran siswa sekolah yang lain di masa-masa mendatang. 


\section{KESIMPULAN DAN SARAN}

Acara penyuluhan dan pelatihan kognitif siswa SMA di Surabaya berjalan dengan lancar disertai antusiasme yang tinggi dari siswa kedua sekolah. Dengan adanya penyuluhan ini terlihat adanya peningkatan pemahaman terhadap siswa-siswa baik SMA Negeri 10 Surabaya maupun SMA Negeri 17 Surabaya terkait antibiotik, resistensi antibiotik dan DAGUSIBU yang dibuktikan dengan hasil poster dan kemampuan berdiskusi pada sesi presentasi.

\section{UCAPAN TERIMA KASIH}

Kegiatan ini didanai oleh dana RKAT Fakultas Farmasi Universitas Airlangga tahun 2018.

\section{DAFTAR PUSTAKA}

Davies, J., \& Davies, D. (2010). Origins and Evolution of Antibiotic Resistance. Microbiology and Molecular Biology Reviews, 74(3), 417-433. https://doi.org/10.1128/MMBR.0001610

Hurlock, Elizabeth, B. 1999. Psikologi Perkembangan: "Suatu Pendekatan Sepanjang Rentang Kehidupan" (Terjemahan Istiwidayanti \& Soedjarno). Jakarta: Penerbit Erlangga.

Levy, S. (1998). The Challenge of Antibiotic Resistance. Scientific American, 278(3), 46-53. Retrieved from http://www.jstor.org/stable/26057703

Witte, W. (1998). Medical Consequences of Antibiotic Use in Agriculture. Science, 279(5353), 996 LP-997. Retrieved from http://science.sciencemag.org/content/2 79/5353/996.abstract 